\title{
Assay of rifampicin in serum
}

\author{
JEAN M. DiCKinson, V. R. ABER, B. W. Allen, G. A. Ellard, AND \\ D. A. MITCHISON \\ From the Medical Research Council's Unit for Laboratory Studies of Tuberculosis, Royal \\ Postgraduate Medical School, Ducane Road, London
}

SYNOPSIS Two methods for the assay of rifampicin in serum are described. The first is a conventional plate diffusion method, measuring concentrations down to $0.02 \mu \mathrm{g} / \mathrm{ml}$, and the second a chemical extraction followed by measurement of the inhibition of uptake of ${ }^{14} \mathrm{C}$-uridine by Staphylococcus aureus, which estimates in the range of 0.02 to $0.001 \mu \mathrm{g} / \mathrm{ml}$. The methods were used to measure serum concentrations in man following doses of about $1050 \mathrm{mg}$ and $75 \mathrm{mg}$ rifampicin.

The use of rifampicin in intermittent regimens for the treatment of tuberculosis has the advantages of reducing the high cost of the drug and allowing full supervision of drug taking but is accompanied by side effects, probably immunological in origin (Poole, Stradling, and Worlledge, 1971; Aquinas, Allan, Horsfall, Jenkins, Wong, Girling, Tall, and Fox, 1972). Amongst various methods under investigation which might eliminate these side effects is the prescription of a small daily dose of rifampicin to be taken on the days between the larger therapeutic intermittent doses. Such an attempt to induce immunological tolerance is currently under study in Hong Kong using a daily dose of $75 \mathrm{mg}$ rifampicin and in Singapore using $25 \mathrm{mg}$. The preliminary results of the study in Hong Kong suggest that administration of the small daily dose in between weekly doses of 900 to $1200 \mathrm{mg}$ reduced the incidence of the 'flu' syndrome (Hong Kong Tuberculosis Treatment Services/British Medical Research Council, 1974). The serum concentrations attained were studied as they are fundamental to an interpretation of the results. Since the small daily doses used in the two studies were expected to produce concentrations of rifampicin only briefly measurable by conventional plate diffusion assays, a more sensitive method of assay was developed. In this method, serum proteins were precipitated with methanol and rifampicin was then extracted into chloroform and thence into water with the aid of n-heptane. The aqueous extract was evaporated to dryness and dissolved in nutrient broth seeded with Staphylococcus aureus. The rifampicin concentration could be measured as inhibition of the uptake of uridine$\mathrm{C}^{14}$ into the staphylococcal RNA, since it inhibits

Received for publication 14 February 1974. bacterial deoxyribonucleic acid-dependent ribonucleic acid (RNA) polymerase (RNA nucleotidyl transferase E.C.2.7.7.6) (Hartmann, Honikel, Knüsel, and Nüesch, 1967; Wehrli, Knüsel, Schmid, and Staehelin, 1968; Sippel and Hartmann, 1968; Umezawa, Mizuno, Yamazaki, and Nitta, 1968). The present report describes a conventional plate assay which can measure down to $0.02 \mu \mathrm{g} / \mathrm{ml}$ rifampicin, the new method which can measure between 0.02 and $0.001 \mu \mathrm{g} / \mathrm{ml}$, and the serum concentrations obtained with the large and the small doses of rifampicin in patients in the Hong Kong study.

\section{Methods}

ASSAY ORGANISM

Staphylococcus aureus (Staphylococcus subgroup I, NCTC 10702), resistant to streptomycin and other antibiotics (Mitchison, Allen, and Miller, 1970), was used as the test organism in both methods. Samples of an overnight culture in nutrient broth (Oxoid, no. 2) were stored at $-196^{\circ} \mathrm{C}$ and an ampoule was thawed for each assay.

\section{PLATE DIFFUSION ASSAY}

Seeded assay medium was prepared by adding $10 \mu \mathrm{l}$ culture to $100 \mathrm{ml}$ Bacto antibiotic medium no. 1 (Difco, Detroit), modified by the addition of $3 \mathrm{ml}$ $\mathrm{M} \mathrm{KH} \mathrm{KO}_{2} \mathrm{PO}_{4}$, and was dispensed in 10-ml volumes into $9 \mathrm{~cm}$ diameter plates. Four wells, $8 \mathrm{~mm}$ diameter, were cut in each plate. Standards were made by adding rifampicin in two-fold dilutions to pooled human serum to make concentrations from 1.28 to $0.02 \mu \mathrm{g} / \mathrm{ml}$. The standard and unknown sera were each pipetted to fill four wells in separate plates. After overnight incubation at $37^{\circ} \mathrm{C}$, the diameters of the zones of inhibition (including the well) were 
measured with vernier calipers. A linear relationship was found between zone diameter and log rifampicin concentrations (fig 1). Sera containing more than $1.28 \mu \mathrm{g} / \mathrm{ml}$ rifampicin were diluted $1: 40$ in human serum and the test was repeated.

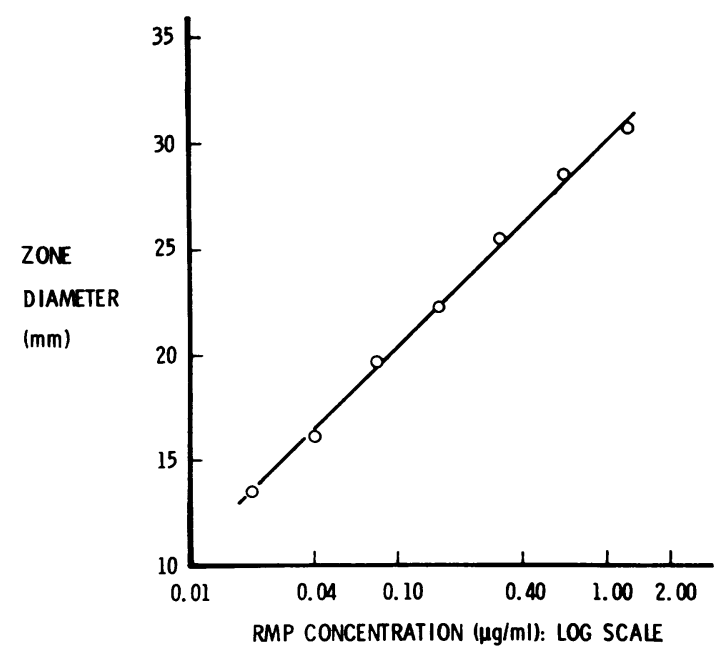

Fig 1 Relationship between the diameter of the zone of inhibition and log rifampicin concentration obtained with standards in a typical plate diffusion assay.

\section{URIDINE UPTAKE ASSAY}

\section{Standards}

Standards were prepared containing $20,10,5,2 \cdot 5$, and $1.25 \mathrm{ng} / \mathrm{ml}$ rifampicin in normal human serum. One sample $(2 \mathrm{ml})$ of each standard and two samples of serum without rifampicin were included in each batch of assays.

\section{Extraction}

Samples of $2 \mathrm{ml}$ serum, in a glass stoppered tube, were mixed with $6 \mathrm{ml}$ methanol to precipitate protein and strip off bound rifampicin. After centrifugation at $0^{\circ} \mathrm{C}, 6 \mathrm{ml}$ of supernatant was removed to a fresh tube, to which was added $3 \mathrm{ml}$ chloroform and 1.5 $\mathrm{ml} 15 \%$ ammonium sulphate solution. After mixing, $3 \mathrm{ml}$ of the lower chloroform phase was transferred to another tube and $4 \mathrm{ml} \mathrm{n}$-heptane added. The tube was gently mixed and two $0.35 \mathrm{ml}$ portions from the lower aqueous phase were transferred to separate tubes. These tubes were placed under reduced pressure on a rotary film evaporator, modified to process five tubes simultaneously, until only a drop of moisture was visible. Drying was completed by storing the tubes overnight over $\mathrm{CaCl}_{2}$ in a vacuum dessicator at $4^{\circ} \mathrm{C}$.

\section{Incorporation of uridine}

Each tube containing dried extract received $0.4 \mathrm{ml}$ of buffered medium $\mathrm{pH} 6.4$, prepared by mixing $5 \stackrel{\overrightarrow{5}}{\rightarrow}$ $\mathrm{ml} 0.5 \mathrm{M}$ tris maleate buffer $\mathrm{pH} 6.6,25 \mathrm{ml}$ nutrient $\bar{C}$ broth (Oxoid no. 2) and $0.6 \mathrm{ml} 0.2 \mathrm{~N} \mathrm{HCl}$, and the contents were dissolved by agitating the tube on a $\frac{\bar{s}}{\frac{}{a}}$ Vortex mixer. To each tube was added $0.1 \mathrm{ml}$ of $a \stackrel{\varnothing}{\varnothing}$ mixture of $4.5 \mathrm{ml}$ nutrient broth, $0.3 \mathrm{ml}$ of the culture of Staph. aureus, and $10 \mu \mathrm{C}$ in $0.2 \mathrm{ml}{ }^{14} \mathrm{C}$-uridine (uridine $-2-{ }^{14} \mathrm{C}$, specific activity about $60 \mu \mathrm{C} / \mathrm{mM}$, $\stackrel{\circ}{\circ}$ Radiochemical Centre, Amersham). After incubation $\vec{\omega}$ in a water bath for three hours at $37^{\circ} \mathrm{C}$, incorporation $\stackrel{S}{\circ}$ was terminated by the addition of $5 \mathrm{ml} 5 \%(\mathrm{w} / \mathrm{v})$ 용 trichloracetic acid. The organisms were collected in on glass fibre paper discs (Whatman, grade GF/A) dried and counted in toluene containing $7 \mathrm{~g} / \mathrm{l}$ iे 2(4-tert-butylphenyl) 5(4-biphenylyl) 1-3-4 oxadiazole 7 in an Intertechnique ABAC 40 scintillation counter. 옥 Serum without rifampicin yielded about $60000 \mathrm{cpm} \rightarrow$ and serum with an excess of rifampicin about $120 \subseteq$ cpm.

\section{Calculation}

A plot of $\log \mathrm{cpm}$ against log rifampicin concentration was sigmoid. Approximate linearity was obtained over the range $1-20 \mathrm{ng} / \mathrm{ml}$ if the counts were transformed to $\log \left(\frac{\mathbf{R}}{1-\mathbf{R}}\right)$, where $\mathbf{R}$ is the ratio of the activity (cpm) of the test serum to the mean $\overrightarrow{\overrightarrow{0}}$ activity of the two sera without rifampicin (fig 2).

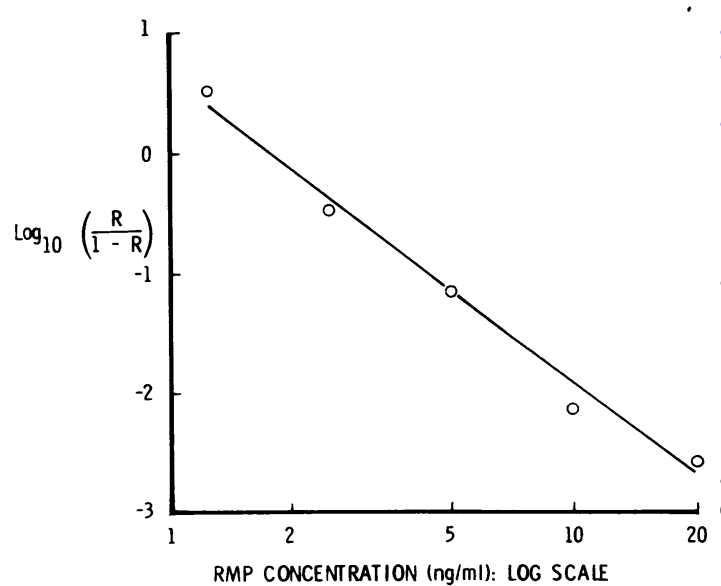

Fig 2 Relationship between $\log _{10}\left(\frac{R}{I-R}\right)$ and log rifampicin concentration obtained with standards in a typical uridine uptake assay. $R$ is the ratio of the activity of a standard serum containing rifampicin to the mean activity of sera without rifampicin. 


\section{Stability of rifampicin in serum}

Samples of human serum containing known concentrations of rifampicin were stored at $-20^{\circ} \mathrm{C}$ and assayed at intervals of up to 33 days. No change in the concentrations occurred.

\section{Serum for standards}

No alternative to human serum for the preparation of standards was found. Considerably less rifampicin was recovered from aqueous solutions than from serum, suggesting that substances in serum, which passed through the extraction procedure, were protecting against adsorption of rifampicin onto the glassware. Recovery from horse serum and 4\% solutions of bovine or human albumin was higher than from water but considerably lower than from human serum. The curve obtained with fresh frozen human plasma was similar in shape to the curve with human serum, but insufficiently close to allow its use.

\section{Glassware}

To avoid transmission of adsorbed rifampicin from one experiment to the next, scrupulous washing of all glassware proved essential. Tubes were scrubbed in Pyroneg (Diversey Ltd, Cockfosters, Herts) solution, rinsed in tap water, left in $\mathrm{N} \mathrm{HCl}$ overnight and rinsed with water, methanol, and acetone before re-use. Fresh pipettes, usually disposable, were used for each dilution. Failure to observe these precautions resulted in spuriously low counts in some tubes.

\section{PATIENTS}

Blood was collected from 10 Chinese patients admitted to a study of reserve drugs for the treatment of pulmonary tuberculosis (Hong Kong Tuberculosis Treatment Services/British Medical Research Council, 1974). These patients received at weekly intervals a dose of rifampicin of about $23 \mathrm{mg} / \mathrm{kg}$ body weight $(900 \mathrm{mg}$ for patients of less than $40.9 \mathrm{~kg}$, $1050 \mathrm{mg}$ for $40 \cdot 9-49 \cdot 5 \mathrm{~kg}$, and $1200 \mathrm{mg}$ for $50 \mathrm{~kg}$ or more), $90 \mathrm{mg} / \mathrm{kg}$ ethambutol, and approximately $66 \mathrm{mg} / \mathrm{kg}$ pyrazinamide given at the same time. On each day between the weekly doses they were also given a daily supplement of either $75 \mathrm{mg}$ rifampicin or of a matching placebo. Blood was collected from patients allocated to the rifampicin-containing supplement after they had received at least one month of chemotherapy. Samples from the same patients were taken at intervals over a 48-hour period following one of the high weekly doses, but omitting the supplement during the collection period, and over a 24-hour period after a dose of supplement on the sixth day after the high weekly dose. The timing of rifampicin dosage in relation to food was the same as in the main study. The high weekly doses were given one and a quarter hours after a light breakfast. The supplement was given in the morning before food, except that patient 9 had taken breakfast one and a half hours previously.

\section{Results}

ACCURACY OF ASSAYS

In the plate diffusion method, the $95 \%$ fiducial limits of estimates of rifampicin concentrations in individual sera varied from $\pm 20 \%$ to $\pm 25 \%$ when the estimate was near the middle of the range of the standard concentrations to $\pm 40-50 \%$ near the extremities of the standard concentration range. The $95 \%$ fiducial limits for the uridine uptake method were approximately $\pm 30 \%$ for values near the middle of the standard concentration range.

\section{RELATIVE ACTIVITIES OF RIFAMPICIN AND DESACETYL RIFAMPICIN}

Desacetyl rifampicin (DARMP) is the principal metabolite of rifampicin and retains part of its antibacterial activity (Maggi, Vigevani, and Pallanza, 1968). However, the relative activity of rifampicin and desacetyl rifampicin varies from organism to organism. A comparison was therefore made of their relative activities against the test Staph. aureus and against Mycobacterium tuberculosis. For the experiment with $M$. tuberculosis, 11 drugsensitive strains were obtained before chemotherapy from patients in Singapore and Hong Kong and, with strain H37Rv, were tested by the linear diffusion method of Lloyd and Mitchison (1964). In experiments 1 and 2 concentrations of $0.2,0.6$, and 1.8 $\mu \mathrm{g} / \mathrm{ml}$ rifampicin and $0.6,1.8$, and $5.4 \mu \mathrm{g} / \mathrm{ml}$ desacetyl rifampicin were prepared in sterile water or human serum and were assayed in triplicate on plates seeded with Staph. aureus (fig 3). A good fit was obtained to the lines relating log concentration to zone diameter for rifampicin and desacetyl rifampicin and these lines were parallel, indicating similar diffusion rates of the two compounds. Experiment 3 was conducted in a similar manner with $M$. tuberculosis. The lines for rifampicin and desacetyl rifampicin again appeared parallel, but there were significant though small departures from linearity $(0.025<P<0.05)$, a finding that does not invalidate the estimation of relative activity. Staph. aureus required about 4.5 times as much desacetyl rifampicin as rifampicin to produce zones of the same size (table I). The corresponding estimate for M. tuberculosis was $\mathbf{2 \cdot 2 \text { . }}$

COMPARISON OF PLATE DIFFUSION AND URIDINE UPTAKE ASSAYS

Serum specimens from patients receiving rifampicin 


\begin{tabular}{|c|c|c|c|c|c|}
\hline $\begin{array}{l}\text { Experiment } \\
\text { No. }\end{array}$ & Organism & Diluent & $\begin{array}{l}\log _{10} D A R M P^{1} / \\
R M P\end{array}$ & $S E$ & $\begin{array}{l}\text { DARMPI } \\
\text { RMP }\end{array}$ \\
\hline $\begin{array}{l}1 \\
2 \\
3\end{array}$ & $\begin{array}{l}\text { Staph. aureus } \\
\text { Staph. aureus } \\
\text { M. tuberculosis }\end{array}$ & $\begin{array}{l}\text { Water } \\
\text { Water } \\
\text { Serum } \\
\text { Water }\end{array}$ & $\begin{array}{l}0 \cdot 69 \\
0 \cdot 60 \\
0 \cdot 65 \\
0 \cdot 34\end{array}$ & $\begin{array}{l}0.034 \\
0.027 \\
0.035 \\
0.050\end{array}$ & $\begin{array}{l}4 \cdot 9 \\
4 \cdot 0 \\
4 \cdot 5 \\
2 \cdot 2\end{array}$ \\
\hline
\end{tabular}

Table I Relative microbiological activities of RMP and DARMP

${ }^{1}$ Concentrations of desacetyl rifampicin (DARMP) and rifampicin (RMP) which produce the same diameter of zone of inhibition.

which had low concentrations of the antibiotic by the plate diffusion method were appropriately diluted in normal human serum and assayed by the uridine uptake method (table II). The two sets of estimates agreed well.

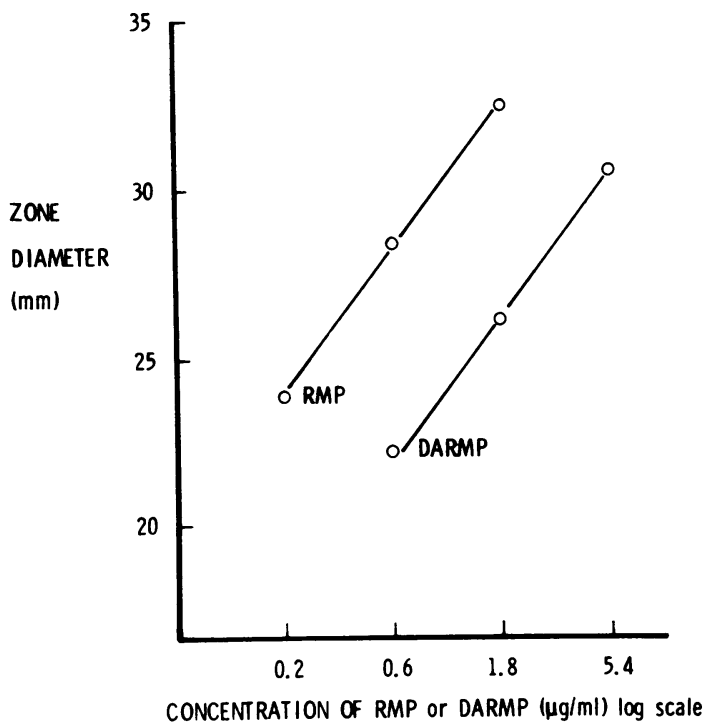

Fig 3 Estimation of the relative activity of rifampicin and desacetylrifampicin against Staph. aureus in the diffusion assay. The lines show the relationships between the diameter of the zone of inhibition and log rifampicin or desacetyl rifampicin concentrations.
SERUM CONCENTRATIONS

The serum concentrations of rifampicin following $\vec{\omega}$ the high weekly dose are set out in table III and? following the supplement in table IV. Peak concentrations usually occurred at two to four hours afterin either dose. The mean of the highest concentration ${ }^{2}$ measured for each patient was $21.2 \mu \mathrm{g} / \mathrm{ml}$ following the high dose and $0.55 \mu \mathrm{g} / \mathrm{ml}$ following the supple- $\gamma$ ment dose. Thus the mean peak concentration after음 the high dose was 34 times higher than after thesupplement, although the size of the high dose was $\subsetneq$ only about 14 times larger than the supplement $\vec{\odot}$ dose. After the high dose of rifampicin, the serum $\overrightarrow{0}$ concentrations of the 10 patients fell on average $\perp$ during the periods $4-12,12-24,24-32$, and $32-48$. hours by rates equivalent to half-lives of $4 \cdot 4,2 \cdot 4$, $3 \cdot 7$, and $7 \cdot 2$ hours, respectively. Half-lives of $2 \cdot 2$ and

\begin{tabular}{llll}
\hline $\begin{array}{l}\text { Serum } \\
\text { Number }\end{array}$ & $\begin{array}{l}\text { Estimated Rifampicin } \\
\text { Concentration }(\mu \mathrm{g} / \mathrm{ml})\end{array}$ & $\begin{array}{l}\text { Dilution of Serum } \\
\text { for Uridine } \\
\text { Uptake }\end{array}$ \\
\cline { 2 - 4 } & Plate Diffusion & Uridine Uptake & \\
\hline 1 & 0.023 & 0.023 & Neat \\
2 & 0.025 & 0.023 & Neat \\
3 & 0.040 & 0.052 & $1: 4$ \\
4 & 0.048 & 0.054 & $1: 4$ \\
5 & 0.056 & 0.069 & $1: 4$ \\
6 & 0.25 & 0.26 & $1: 20$ \\
7 & 0.34 & 0.29 & $1: 20$ \\
Geometric & & & \\
mean & 0.066 & 0.069 & \\
\hline
\end{tabular}

Table II Comparison of plate diffusion and uridine uptake assays

\begin{tabular}{|c|c|c|c|c|c|c|c|c|c|c|}
\hline \multicolumn{2}{|c|}{ Patient } & \multirow{2}{*}{$\begin{array}{l}\text { Rifampicin } \\
\text { Dose } \\
\text { (mg) }\end{array}$} & \multicolumn{8}{|c|}{ Time after Dose (hr) } \\
\hline No. & Weight $(k g)$ & & 1 & 2 & 4 & 8 & 12 & 24 & 32 & 48 \\
\hline 1 & 45 & 1050 & $11 \cdot 3$ & $16 \cdot 6$ & $27 \cdot 0$ & 14.0 & 4.90 & 0.35 & 0.070 & 0.014 \\
\hline 2 & 46 & 1050 & 0.62 & $7 \cdot 31$ & 18.9 & 17.0 & 3.53 & 0.20 & 0.051 & 0.007 \\
\hline 3 & 43 & 1050 & $8 \cdot 57$ & $24 \cdot 1$ & $19 \cdot 7$ & $7 \cdot 19$ & 6.07 & 0.058 & 0.006 & 0.002 \\
\hline 4 & 46 & 1050 & 6.00 & 26.0 & $28 \cdot 7$ & $27 \cdot 2$ & $22 \cdot 2$ & 1.48 & 0.20 & 0.038 \\
\hline 5 & 63 & 1200 & $1 \cdot 15$ & $6 \cdot 20$ & $15 \cdot 5$ & $5 \cdot 56$ & 3.44 & $0 \cdot 14$ & 0.022 & 0.002 \\
\hline 6 & 40 & 900 & $1 \cdot 38$ & $38 \cdot 3$ & $36 \cdot 1$ & 36.9 & $11 \cdot 3$ & 0.61 & 0.13 & 0.025 \\
\hline 7 & 47 & 1050 & $34 \cdot 4$ & $48 \cdot 5$ & $20 \cdot 6$ & $12 \cdot 2$ & $10 \cdot 2$ & $0 \cdot 10$ & 0.039 & 0.014 \\
\hline 8 & 49 & 1050 & 0.70 & 20.5 & $23 \cdot 0$ & 7.92 & 3.97 & 0.069 & 0.039 & 0.010 \\
\hline 9 & 54 & 1200 & 0.40 & 5.94 & $11 \cdot 8$ & $4 \cdot 72$ & 1.50 & 0.041 & 0.016 & 0.002 \\
\hline 10 & 45 & 1050 & $7 \cdot 27$ & $23 \cdot 6$ & $19 \cdot 9$ & $13 \cdot 3$ & $10 \cdot 3$ & 0.38 & 0.060 & 0.031 \\
\hline \multicolumn{3}{|c|}{ Geometric mean } & $2 \cdot 89$ & $17 \cdot 38$ & $21 \cdot 2$ & 11.9 & 5.96 & $0 \cdot 19$ & 0.042 & 0.0089 \\
\hline
\end{tabular}

Table III Serum concentrations of rifampicin $(\mu \mathrm{g} / \mathrm{ml})$ after high dose 


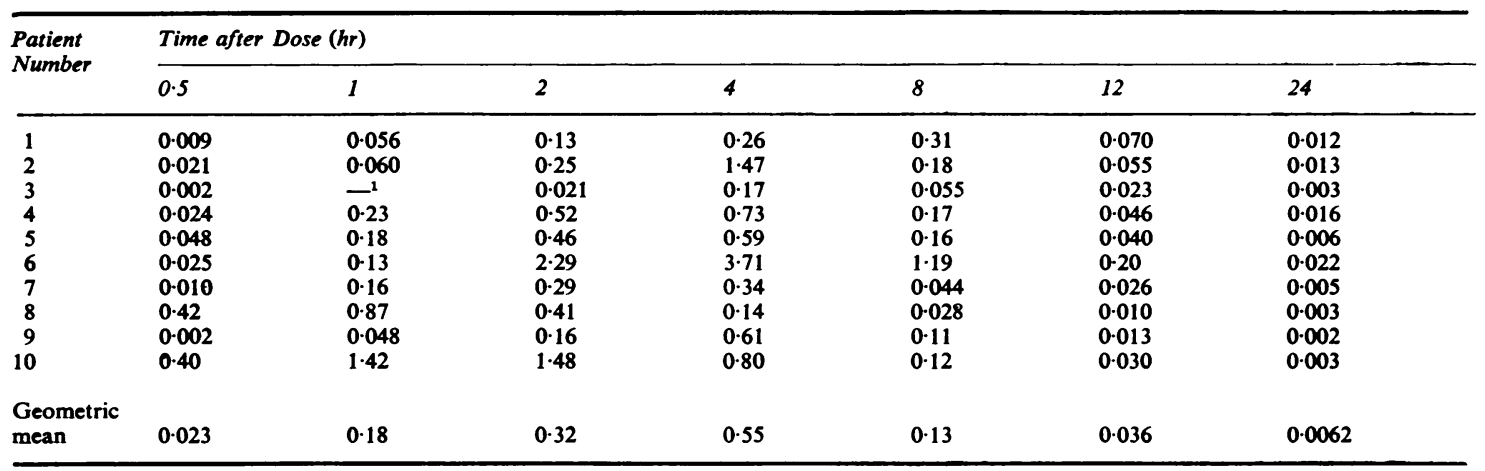

Table IV Serum concentrations of rifampicin $(\mu \mathrm{g} / \mathrm{ml})$ after $75 \mathrm{mg}$ dose

'No specimen obtained.

4.7 hours, respectively, were calculated for the same patients over the period of eight to 12 and 12 to 24 hours after a dose of the supplement when serum rifampicin concentrations were similar to those found at 24-32 and 32-48 hours after the high dose. The estimates of half-lives during these comparable periods were significantly shorter for the supplement than for the high dose $(P<0.01$ and $P<0.05$ for the earlier and later periods, respectively). Variance analysis showed no evidence of variation in half-life from patient to patient

\section{Discussion}

Staph. aureus was chosen for several reasons as the test organism in preference to Sarcina lutea used by many other workers. Experience with the strain obtained from the National Collection of Type Culture (Micrococcus subgroup 1 NCTC 8340) suggested that it contained variants with different degrees of sensitivity to rifampicin and desacetyl rifampicin. Furthermore, the edge of the zone inhibition was less sharp and a longer incubation period was necessary before readings of the zone of incubation could be made.

A comparison of the relative activities of rifampicin and its metabolite desacetyl rifampicin showed that $M$. tuberculosis was relatively more sensitive to the metabolite than Staph. aureus. Since serum from patients treated with rifampicin contains desacetyl rifampicin, assays with Staph. aureus will slightly underestimate the total activity against $M$. tuberculosis. Estimates of the relative activities of rifampicin and desacetyl rifampicin for $S$. lutea, Bacillus bovis, and $M$. tuberculosis have been made previously by Cannetti, Djurovic, Le Lirzin, Thibier, and Lepeuple, (1970). Their estimate for $M$. tuberculosis, obtained by the inherently less accurate method of serial twofold dilution, was similar to our estimate of $2 \cdot 2$. For the reasons stated above, we could not confirm their estimate for $S$. lutea.

The uridine uptake method of assay is considerably more time-consuming and difficult to standardize than the plate assay. This method was developed for measuring concentrations following low doses of rifampicin whose use is being explored in the prevention of toxicity occurring during intermittent dosage of the drug and for other reasons. For most purposes, however, the plate assay, capable of measuring down to $0.02 \mu \mathrm{g} / \mathrm{ml}$, is sufficiently sensitive since the drug is used mainly for the treatment of tuberculosis and the minimal inhibitory concentration for $M$. tuberculosis is about $0 \cdot 3 \mu \mathrm{g} / \mathrm{ml}$.

The disproportion between peak serum concentrations and dose size and the slower elimination of rifampicin demonstrated four to eight hours after giving the high dose to the Hong Kong patients is similar to the results previously obtained by Furesz, Scotti, Pallanza, and Marpelli (1967) in man and by Dickinson and Mitchison (1970) in the guinea pig. The slower elimination of the high doses of rifampicin is probably due to saturation of biliary excretion of the drug. However, the differences noted in the initial rates of elimination of the high dose and supplement do not fully account for the disproportion in the peak rifampicin concentrations found. It is therefore suggested that there must be a 'sink', possibly of hepatic origin, that binds a greater proportion of the supplement than of the high rifampicin dose. Subsequent slow release from this sink could explain the differences in the rates of elimination of the two doses occurring at similar serum concentrations. The slower elimination of rifampicin noted after both doses when the serum concentrations fell below $0.04 \mu \mathrm{g} / \mathrm{ml}$ could have been due to release of rifampicin from protein binding. The immunological implications of the measurements of the serum concentrations following the large 
weekly dose and the smaller daily supplement are discussed elsewhere (Hong Kong Tuberculosis Treatment Services/British Medical Research Council, 1974).

We are grateful to Sister M. Gabriel, Ruttonjee Sanatorium, Hong Kong, for collecting blood from the patients.

\section{References}

Aquinas, M., Allan, W. G. L., Horsfall, P. A. L., Jenkins, P. K., Wong, H. Y., Girling, D., Tall, R., and Fox, W. (1972). Adverse reactions to daily and intermittent rifampicin regimens for pulmonary tuberculosis in Hong Kong. Brit. med. J., 1, 765-771.

Canetti, G., Djurovic, V., Le Lirzin, M., Thibier, R., and Lepeuple, A. (1970). Étude comparative de l'évolution des taux sanguins de rifampicine chez l'homme par deux méthodes microbiologigues différentes. Rev. tuberc. (Paris), 34, 93-106.

Dickinson, J. M., and Mitchison, D. A. (1970). Suitability of rifampicin for intermittent administration in the treatment of tuberculosis. Tubercle, 51, 82-94.

Furesz, S., Scotti, R., Pallanza, R., and Marpelli, E. (1967). Rifam- picin: a new rifamycin. III- Absorption, distribution and elimination in man. Arzneimittel Forsch., 17, 534-537.

Hartmann, G., Honikel, K. O., Knüsel, F., and Nüesch, J. (1967): The specific inhibition of the DNA-directed RNA synthesis by rifamycin. Biochim. biophys. Acta (Amst.), 145, 843-844.

Hong Kong Tuberculosis Treatment Services/British Me dical Researcto Council (1974). A controlled clinical trial of small daily doses of rifampicin in the prevention of adverse reactions to the drug in a once-weekly regimen of chemotherapy. Clin. Allergy, in press.

Lloyd, J., and Mitchison, D A. (1964). A vertical diffusion method for the microbiological assay of isoniazid. J. clin. Path. थ 17, 622-626.

Maggi, N., Vigevani, A., and Pallanza, R. (1968). Desacetyl-rifamycins $\overrightarrow{0}$ preparation and antibacterial properties. Experientia (Basel) 24, 209-211.

Mitchison, D. A., Allen, B. W., and Miller, A. B. (1970). Detection of rifampicin in urine by a simple microbiological assay. Tubercle $51,300-304$.

Poole, G., Stradling, P., and Worlledge, S. (1971). Potentially serious side effects of high-dose twice-weekly rifampicin. Brit. med.J., V 3, 343-347.

कृ

Sippel, A., and Hartmann, G. (1968). Mode of action of rifamycin oni the RNA polymerase reaction. Biochim. biophys. Acta (Amst.) or 157, 218-219.

Umezawa, H., Mizuno, S., Yamazaki, H., and Nitta, K. (1968)음 Inhibition of DNA-dependent RNA synthesis by rifamycins. J. Artibiot. (Tokyo), 21, 234-236.

Wehrli, W., Knüsel, F., Schmid, K., and Staehelin, M. (1968). Interaction of rifamycin with bacterial RNA polymerase. Proc. nat. Acad. Sci. (Wash.), 61, 667-673. 